\title{
Education and Training as an Effort in Increasing Teacher's Competence and the Impact Towards Learning Achievement
}

\author{
Slamet Fauzan ${ }^{1 *}$, Karina Ayuningtyas ${ }^{2}$, Agfia Fauziatul Ulfa ${ }^{3}$ \\ ${ }^{1,2,3}$ State University of Malang \\ ${ }^{*}$ Corresponding author. Email: slamet.fauzan.fe@um.ac.id
}

\begin{abstract}
The background of this study began from the problem that Senior High School students in Semarang regency got low score in accounting, the purpose of this study is to explore the competency of accounting teacher and the students' achievement by analysing teachers' competence and the students' achievement for one semester. The result of this research shows that four teachers' competence affected the students' achievement. The education and the training conducted by the teachers also give impact in the relationship of teachers' competence and the students' achievement.
\end{abstract}

Keywords: Teacher's Competence, Learning Outcomes, Education and Training

\section{INTRODUCTION}

In the learning process, teacher is the most responsible person towards the education quality (Prodjo, 2020; Ratnasari \& Sukirno, 2018). Basically, teacher is a professional educator with the main duty, educating, teaching, supervising, training, and evaluating the students in formal education (Ratnasari \& Sukirno, 2018; Law, No. 14/2005). In doing the duty as the professional educator, teachers need to have four main competences, they are pedagogic competence, professional competence, social competence, and self-competence (Law, No. 14/2005; Saragih, 2008). However, the fact is different, there are many teachers in Indonesia who have competence below the standard (Makkl, 2020; Ramadhan, 2020). Makkl added that it becomes a problem for education world, because it can affect the process and the success in learning process (Ratnasari \& Sukirno, 2018). Because of that, teachers need to have competence in order to be able to create an effective learning environment and able to manage a better teaching and learning process.

According to Dewi, et. al (2014), Learning achievement is an achievement from learning process which can be seen from the students' report. Based on the survey which conducted by researchers, the total National Examination score in the School Year 2008/2009 of Public Senior High School Majoring Social Study in Central Java was not optimum. It is also supported with the finding that there were some students who got the score below the minimum standard of each school. From 54 of 250 students got the score below the minimum standard and stated incomplete. The unachieved of the learning achievement is affected by various factors, both internal and external (Ratnasari \& Sukirno, 2018; Dewi, et. Al, 2014). The internal factors are competency, interest, effort, motivation, student's studying habit, whereas the external factors are physical or non-physical environment in study, socio-cultural environment, family, curriculum, teacher, learning implementation, and peers at school.

The learning is not optimal because teachers' ability is still in low level (Ramadhan, 2020; Sennen, 2017). To solve the problem, the government has tried to help to increase the teachers' competence gradually by holding education and training. The more often the teacher participates in the education and training, the better quality will the teachers have. Moreover, education and training are very important because it becomes one component of portfolio assessment for teachers' certification. Based on the previous research, the researcher has observed some research about competence and learning achievement (Sari, et. Al, 2020; Werdayanti, 2008), but the research about teacher education and training towards students' achievement is not available yet. Based on the previous research and the phenomenon in Indonesia, the researchers do the research to know how competence affect students' achievement and do 
education and training affect the relationship between competence and students' achievement.

\section{LITERATURE REVIEW}

\subsection{Teacher's Competence}

Competence described as person's ability or characteristic in completing their responsibility in their work (Nurtanto, 2014; Sobandi, 2010). Teachers' competence is mastering all materials, knowledge, ethics and having skill in carrying out the tasks professionally. Teachers' success in doing the duty can be seen from how teachesr plan the effectiveness of learning and students' needs. Teacher as the important aspect in learning need to have competence and develop it (Mayasari, 2018). There are four teachers' competence, they are pedagogic competence, professional competence, social competence, and personality competence (Law, No.14/2005; PP. No. 74/2008; Mayasari, 2018).

\subsubsection{Pedagogic Competence}

This competence is the teachers' competence in class control by understanding the students' characteristic entirely and creating an effective learning and also educating them. Moreover, to evaluate learning outcomes and to develop students' potency (Gedot, et. Al, 2013). According to Marshall and Sorto (2012), teachers also need to know how the students learn and master teaching methods in a certain academic.

\subsubsection{Personality Competence}

Teacher is one of important figure in someone's success, because teachers have the personality characteristic which affects students. The personality characteristic of teachers such as sincerity, noble character and high-minded are the important factor in the duty to develop students' good characteristic.

\subsubsection{Professional Competence}

In this competence, teachers should be able to control and master lesson material entirely. In teaching, teachers are not only occupied to be professional, but also able to see and understand various students' thinking plan (Hill and Chin, 2018; Mahanal, 2014).

\subsubsection{Social Competence}

Social competence is the last competence which needs to be applied by the teachers. They have to be able to communicate and interact with students, their colleagues and people around them, including parents and the society (Law, No. 14/2005; Mayarsi \& Syarif, 2018).

\subsection{Achievement of Economic Accounting}

According to Sobandi (2010), achievement is the result of the satisfaction which is achieved by students from the learning which is given to students based on the knowledge, seriousness, and ability in doing the task. Achievement is also a reflection of the teaching result based on their competences. Moreover, a certain major also affects students' achievement. Therefore, teachers need to take training in a certain subject (Guimarães, et. al, 2013; Harris \& Sass, 2011).

In line with the previous research conducted by Evertson, et. al (1985) and Denton and Lacina (1982) which stated that there is a positive impact among teachers' professional education training towards students' achievement. The high achievement of the students is related to the teachers' opportunity in professional development training which is continuously cultivated in pedagogic competence related to the new curriculum for teaching (Rowan \& Ball, 2005; Brown \& Barlow, 1995). Moreover, students' achievement in Economic Accounting subject is one of the achievements achieved by the students in learning activity at school in order to achieve understanding in accounting lesson.

The success of accounting achievement is showed with the numbers reflecting on how far the students understand and master economic accounting material which was taught by teachers in class. The success of the students' achievement in studying accounting will not be optimum without the intention and the willingness from the students and the support and supervision from teachers and parents.

\subsection{Education and Training}

To increase the competence, teachers need to develop their competence (Pangestika \& Alfarista, 2015). The various form of training program such as in-house training (IHT) in internal KKG/MGMP, internship, school partnership, online learning, step by step training, and special training, short course in LPTK, internal supervision from the school, and advance education aim to increase teachers competences. Furthermore, Teacher Professional Education is a program of advance education conducted after graduates from the university which is required to apply for the profession with certain skills (Pangestika \& Alfarista, 2015; Goldhaber \& Brewer, 2000). This education program is arranged by the government to provide teachers' skills and competences (Goldhaber \& Brewer, 2000).

Based on the previous studies, researchers propose two hypothesizes:

$\mathrm{H}_{1}$ Teacher competence has positive impact towards the students' achievement. 
$\mathrm{H}_{2}$ Education and training has positive impact towards the relationship of teacher's competence and students' achievement.

\section{RESEARCH METHOD}

This study used explanatory quantitative method to examine the correlation among independent variable (teachers competence), dependent variable (students' achievement), and intervening variable (education and training). There are 4 teachers competences, namely pedagogic competence, professional competence, social competence, and personality competence (Law, No. 14/2005; PP, No. 74/2008). These competences are measured by giving the questions to accounting teachers in Public High School in Semarang regency trough questionnaires. The questionnaires distributed to 32 accounting teachers in 11 Public High School in Semarang regency. The technique for the sample used purposive sampling because it was carried out directly towards the desired subjects. Next, to measure dependent variable (students' achievement) conducted by documentation techniques because the result of the final score in the students' report became the mark in measuring. The reason to use the final score in the report as the sample of the students' achievement is due to the students got the score after participating in the complex accounting learning phase (Umami \& Roesminingsih, 2014). Next, intervening variable used was education and training. Education and training measured in the questionnaires. The reason to take education and training was to find out how the implementation result after teachers participated in various training and education. Table 1 shows the result of the sample done.

Table 1. Research Sample

\begin{tabular}{clc}
\hline No & \multicolumn{1}{c}{ School } & $\begin{array}{c}\text { The number of } \\
\text { the teachers }\end{array}$ \\
\hline 1 & SMA N 1 Ungaran & 4 \\
2 & SMA N 2 Ungaran & 5 \\
3 & SMA N 1 Bergas & 3 \\
4 & SMA N 1 Ambarawa & 3 \\
5 & SMA N 1 Tuntang & 2 \\
6 & SMA N 1 Bringin & 3 \\
7 & SMA N 1 Pabelan & 2 \\
8 & SMA N 1 Getasan & 2 \\
9 & SMA N 1 Suruh & 3 \\
10 & SMA N 1 Tengaran & 3 \\
11 & SMA N 1 Susukan & 2 \\
\hline & Total & $\mathbf{3 2}$ \\
\hline
\end{tabular}

The data analysis used multiple linear regression technique with the formula as follow:

$$
\begin{aligned}
Z= & a+b_{1} X_{1}+b_{2} X_{2}+b_{3} X_{3}+b_{4} X_{4}+e \\
Y= & b_{6}\left|X_{1}-Z\right|+b_{7}\left|X_{2}-Z\right|+b_{8}\left|X_{3}-Z\right|+b_{9} \mid X_{4} \\
& -Z \mid+e
\end{aligned}
$$

Where:

$\mathrm{Y}=$ Dependent Variable (Students' Achievement).

$\mathrm{a}=$ Constanta of Multiple Regression

$\mathrm{b}_{1}=$ Coeffision regression of teacher's pedagogic competence

$\mathrm{b}_{2}=$ Coeffision regression of teacher's professional competence

$\mathrm{b}_{3}=$ Coeffision regression of teacher's personality competence

$\mathrm{b}_{4}=$ Coeffision regression of teacher's social competence

$b_{5}=$ Coeffision regression of teacher's education and training

$\mathrm{b}_{6}=$ Coeffision regression $\mathrm{X} 1$ which is intervented

$\mathrm{b}_{7}=$ Coeffision regression $\mathrm{X} 2$ which is intervented

$\mathrm{b}_{8}=$ Coeffision regression $\mathrm{X} 3$ which is intervented

$\mathrm{b}_{9}=$ Coeffision regression $\mathrm{X} 4$ which is intervented

$\mathrm{X}_{1}=$ Independent Variable (teacher's pedagogic competence)

$\mathrm{X}_{2}=$ Independent Variable (teacher's professional competence)

$\mathrm{X}_{3}=$ Independent Variable (teacher's personality competence)

$\mathrm{X}_{4}=$ Independent Variable (teacher's social competence)

$\mathrm{Z}=$ Intervening Variable (teacher's education and training)

\section{RESULTS AND DISCUSSION}

Table 2 shows descriptive statistic result from each variable, they are dependent variables, independent variables, and intervening variables. The average score of accounting teachers' competence is still low. It can be seen from the average score of professional competence, personality competence, and social competence which are under 80 as the target score for the graduation of Teacher Competence Test (Ramadhan, 2020). It is contrast with the average of pedagogic score which is above 80 , that is 106,88 . Next, students' achievement shows the score below average, that is 73,28 . It also indicates that there are still many students who have accounting score below the minimum standard. 
Table 2. Descriptive Statistic

\begin{tabular}{lcrrr}
\hline \multicolumn{1}{c}{ Variable } & Min & Max & Mean & Std. Dev \\
\hline $\begin{array}{l}\text { X Pedagogic } \\
\begin{array}{l}\text { Competence } \\
\text { X }\end{array}\end{array}$ & 85.00 & 123.00 & 106.88 & 11.15 \\
$\begin{array}{l}\text { Competence } \\
\text { X }\end{array}$ & 24.33 & 45.19 & 35.62 & 4.87 \\
$\begin{array}{l}\text { Competence } \\
\text { X } 4 \text { Social }\end{array}$ & 24.60 & 44.80 & 34.98 & 4.33 \\
$\begin{array}{l}\text { Competence } \\
\begin{array}{l}\text { Z Education and } \\
\text { Training }\end{array}\end{array}$ & 15.60 & 30.40 & 24.18 & 3.80 \\
\begin{tabular}{l} 
Y Achievement \\
\hline
\end{tabular} & 64.31 & 80.76 & 73.28 & 4.32 \\
\hline
\end{tabular}

Table 3 shows the analysis of pearson correlation among dependent variables, independent variables, and intervening variables. The result shows that pedagogic competence, professional competence, personality competence, social competence each has positive correlation towards the students' achievement. Education and training as intervening variable also have positive correlation towards the students' achievement.

Table 3. Correlation Analysis

\begin{tabular}{lccccc}
\hline Variable & $\mathbf{1}$ & $\mathbf{2}$ & $\mathbf{3}$ & $\mathbf{4}$ & $\mathbf{5}$ \\
\hline $\mathrm{Y}$ & & & & & \\
$\mathrm{X}_{1}$ & $0.828^{* *}$ & & & & \\
$\mathrm{X}_{2}$ & $0.924^{* *}$ & $0.650^{* *}$ & & & \\
$\mathrm{X}_{3}$ & $0.852^{* *}$ & $0.710^{* *}$ & $0.777^{* *}$ & & \\
$\mathrm{X}_{4}$ & $0.900^{* *}$ & $0.754^{* *}$ & $0.795^{* *}$ & $0.707^{* *}$ & \\
$\mathrm{Z}$ & $0.882^{* *}$ & $0.814^{* *}$ & $0.759^{* * *}$ & $0.746^{* *}$ & $0.845^{* *}$ \\
\hline
\end{tabular}

**. Correlation is significant at the $0.01<0.05$

After the completing the data by classical assumption test, multiple linear regression test was conducted and the result is shown in Table 3. There are two models in this analysis. The first model was done in order to analyse the effect of the independent variables consisting of four competences. They are pedagogic competence, professional competence, social competence, and personality competence towards education and training variable. Next, the second model was done in order to test the effect of independent variables and intervening variables towards dependent variable, that is students' achievement.

Table 4. Regression Result

\begin{tabular}{lcc}
\hline & Model I & Model II \\
\hline (Constant) & -6.794 & 16.894 \\
X $_{1}$ Pedagogic Competence & 0.345 & 3.355 \\
X $_{2}$ Professional Competence & 0.118 & 6.933 \\
X $_{3}$ Personality Competence & 0.124 & 2.607 \\
X $_{4}$ Social Competence & 0.404 & 3.255 \\
Z Education and Training & & 1.304
\end{tabular}

\begin{tabular}{lcc}
$\mathrm{R}^{2}$ & 0.443 & 0.164 \\
Sig. F Test & 27.612 & \\
\hline
\end{tabular}

Based on that regression, there is a deviation constanta $(\alpha)$ between regression equation of model I and model II, from which previously $-6,794$ becomes 16,894 . It is due to intervening variable, education and training change the value of the Constanta. The change of the Constanta caused by the change of students' achievement, so it made the Constanta higher. But, negative Constanta basically did not impact regression equation result, because the value $(\beta)$ is positive (Allen $\&$ Stone, 2005).

The next step is the testing of research hypothesis. The test of the first hypothesis done was $\mathrm{F}$ test. Table 3 showed the result of $F$ test between four teachers' competence and students' achievement. The significant $F$ test means four teacher's competence as dependent variable affected students' achievement. However, the result needs to pass t-test to make sure the impact of each independent variable towards dependent variable.

In the first test model of this research, it showed significance of variable $\mathrm{X}_{1}$ (pedagogic competence) which has significance value $0,21<0,05$, so pedagogic competence affects negatively and significantly towards education and training. Next, significance of professional competence is $0,477>0,05$ which proof that professional competence affects positively and significantly towards education and training. Significance value of personality competence is $0,417>0,05$, it showed that it has positive impact and not significant, and social competence has significance value amount of $0,020<0,05$, which showed that social competence has positive and significance impact towards education and training.

Next, in the second test model, the result showed that the significance of pedagogic competence, professional competence, social competence, and personality competence have positive and significance impact towards the students' achievement. The result of the test showed that $\mathrm{H}_{1}$ could not be rejected. The value of $\mathrm{R}$ Square of teacher's competence is 0,443 which means $43,3 \%$ variability of students' achievement was explained by teacher's competence and the rest was affected by other variables. It is contrast with the result of education training which the result is $>0,05$ or not significant, and has positive impact towards students' achievement. Education and training variable made significance value of teacher's competence decreased, so it can be concluded that education and training was intervening teachers' competence. Therefore, $\mathrm{H}_{2}$ in this research was also could not be rejected. The result of $\mathrm{R}$ Square education and training is 0,164 which means $16,4 \%$ students' achievement affected by education and training, whereas the rest was affected by other variables.

Y Students' Achievement 


\section{DISCUSSION}

\subsection{The Impact of Teacher Competence towards Students' Achievement}

The test result showed that teachers competence gave positive and significant impact towards students' achievement. This result was in line with research conducted by Ratnasari and Sukiro (2018), which stated that the students' perception about teachers' competence has positive impact towards the students' achievement. The students consider that teachers have good competences and can help to increase students' achievement, because teachers motivated the students to keep learning. Teachers' understanding towards the context and skill affecting students' achievement (Guimarães, et. al, 2013; Boyd, et.al, 2009). According to Saragih (2008) and Dudung (20818), in learning process, four teachers' competences also give impact, because between one and other competences supports each other's. It started from pedagogic and professional competence which are required to prepare well-class, start the lesson, create lesson plan, and prepare other learning process (Dewi, et. al, 2014; Umami and Roesminingsih, 2014; Densgombe, 1982; Mas, 2013). Good material explanation will make the students understand the lesson better so it will motivate students to keep learning and get the best result (Mayasari \& Syarif, 2018). However, besides good material explanation and the conducive class, teachers also need social ability to socialize with students in class. Being humble and kind can affect in establishing a good class and gives impact towards learning quality (Mas, 2013; Hakim, 2015).

\subsection{The Impact of Education and Training towards the Correlation of Teacher's Competence towards the Students' Achievement}

The result showed that education and training for teachers intervened the relationship of teachers' competence and students' achievement. According Marshall \& Sorto (2012) and Harris \& Sass (2011), education and training for the teachers increase teachers' competence and knowledge which become the key in increasing education quality. Training which focused on class work and learning opportunities creates more an effective learning compared to teachers who teach based on theory (Prasetia, 2020). If teachers more participate in the education and training, it will support and increase the ability (Prasetia, 2020). However, it would not help the learning process if teachers only participate without practicing afterwards. Although education and training affected teachers' competences, but teachers' competence in Indonesia are still low. It is because the lack of infrastructure and education, and low training quality (Ramadhan, 2020).

\section{CONCLUSIONS}

Teachers become the important component in education world. Through teachers, the quality of the education can increase in a better level. Through various competencies, teachers give the knowledge to the students in order to understand and keep good learning ability. This research was conducted to test the relationship among teachers' competences; pedagogic competence, professional competence, personality competence, and social competence towards students' achievement. Moreover, this study also tests the effect of education and training as intervening variable towards the relationship between teachers' competences and students' achievement.

This study showed that teachers' competence affects students' achievement in accounting subject. Pedagogic competence and professional competence become good competence which have a greater impact compared to others. In learning process, teachers also emphasize and prepare in order to master pedagogic and professional competence started by creating lesson plan, learning materials, and other instruments. This result can become a certain concern for the teachers and educational institute. Teachers' competence not only focuses on the process of material explanation and making teaching instruments, but also teachers need to be able to socialize and have a good personality as a role model for students.

This study also found that education and training affect the relationship between teacher's competence and students' achievement. Government programs for education and training are available through Education and Training Centre, but the result is still not maximum.

The finding in this research can be a consideration for universities and the government, especially Ministry of Education and Culture to fix education and training system to be more practical, not merely theoretical. The government also could reconsider the policy whether it is appropriate to the world development or not.

The limitation in this research is on collecting questionnaires data and could not give the wider view. The suggestion for the next research is to involve teachers' professional education or other legal programs. 


\section{REFERENCES}

[1]. Allen, R. C., \& Stone, J. H. (2005). Textbook Neglect of the Constant Coefficient. Journal Economic Education, 36(4), 379-384.

[2]. Ball, D. L. (1991). Teaching mathematics for understanding: What do teachers need to know about subject matter? In Book Teaching academic subjects to diverse learners (M. Kennedy, Ed). New York City: Teachers College Press.

[3]. Brown, T. A., \& Barlow, D. H. (1995). Longterm outcome in cognitive-behavioral treatment of panic disorder: Clinical predictors and alternative strategies for assessment. Journal Consultancy Clinic Psychology, 63(5), 754-765. doi: 10.1037/0022-006X.63.5.754.

[4]. Boyd, D. J., Grossman, P. L., Lankford, H., Loeb, S., \& Wyckoff, J. (2009). Teacher preparation and student achievement. Educational Evaluation Policy Analysis, 31(4), 416-440. doi: 10.3102/0162373709353129.

[5]. Coleman, J. (1968). The concept of equality of educational opportunity. Harvard Educational Review, 38(1), 7-22.

[6]. Densgombe, M. (1982). The hidden pedagogy and its implications for teacher training. British Journal of Sociology of Education, 3(3), 249265. doi: 10.1080/0142569820030303.

[7]. Dewi, L. R., Suharsono, N., \& Haris, I. A. (2014). Pengaruh kompetensi pedagogik dan kompetensi profesional terhadap hasil belajar siswa dalam mata pelajaran Ekonomi kelas $\mathrm{X}$ SMAN 4 Singaraja. Jurnal Pendidikan Ekonomi, 4(1), 1-11.

[8]. Denton, J. J., \& Lacina, L. J. (1982). Quantity of professional education coursework linked with process measures of student teaching. Journal of Teacher Education and Practice, 1, 39-64.

[9]. Dudung, A. (2018). Kompetensi Profesional Guru. Jurnal Kesejahteraan Keluarga dan Pendidikan, 5(1), 9-19. doi: 10.21009/jkkp.051.02.

[10]. Evertson, C. M., Hawley, W. D., \& Zlotnik, M. (1985). Making a difference in educational quality through teacher education. Journal of Teaching Education, 36(3), 2-12.

[11]. Gidot, S., Mashudi., \& Matsum, J. H. (2013). Pengaruh kompetensi profesional guru dan minat belajar terhadap hasil belajar akuntansi kelas XI. Jurnal Pendidikan dan Pembelajaran
Khatulistiwa. Jurnal Pendidikan dan Pembelajaran Khatulistiwa, 3(3), 1-14.

[12]. Goldhaber, D. D., \& Brewer, D. J. (1988). Teacher licensing and student achievement. Better Teachers and Better School, 83-102.

[13]. Goldhaber, D. D., \& Brewer, D. J. (2000). Does teacher certification matter? High school teacher certification status and student achievement. Educational Evaluation Policy Analysis, 22(2), 129-145. doi: $10.3102 / 01623737022002129$.

[14]. Government Regulation, No. 74/2008, Regarding teachers.

[15]. Guimarães, R., Sitaram, A., Jardon, L., Taguchi, S., \& Robinson, L. (2013). The effect of teacher content knowledge on student achievement: A quantitative case analysis of six Brazilian States. Population Assotiation of America 2013 Annual Meeting, 1-17.

[16]. Hadwin, J., Baron-Cohen, S., Howlin, P., \& Hill, K. (1997). Does teaching theory of mind have an effect on the ability to develop conversation in children with autism? Journal of Autism and Developmental Disorder, 27(5), 519-537.

[17]. Hakim, A. (2015). Contribution of competence teacher (pedagogical, personality, professional competence and social) on the performance of learning. International Journal English Science, 4(2),1-12. Retrieved online from www.theijes.com.

[18]. Harris, D. N., \& Sass, T. R. (2011). Teacher training, teacher quality and student achievement. Journal of Public Economic, 95(7-8), 798-812. doi: 10.1016/j.jpubeco.2010.11.009.

[19]. Hill, H., Rowan, B., \& Ball, D. (2005). Effects of teachers' mathematical knowledge for teaching on student achievement. American Education Research Journal, 42(2), 371-406.

[20]. Hill, H. C., \& Chin, M. (2018). Connections between teachers' knowledge of students, instruction, and achievement outcomes. American Education Research Journal, 55(5), 1076-1112. doi: 10.3102/0002831218769614.

[21]. Law, No. 14/2005, Regarding teachers and lecturers.

[22]. Ma, L. (1999). Knowing and teaching elementary mathematics: Teachers' understanding of fundamental mathematics in 
China and the United States. New Jersey: Lawrence Erlbaum Associates.

[23]. Mahanal, S. (September, 2014). Peran guru dalam melahirkan generasi emas dengan keterampilan abad 21. Seminar Nasional Pendidikan HMPS Pendidikan Biologi FKIP Universitas Halu Oleo, 1, 1-16, Kendari.

[24]. Makkl, S. (November 27th, 2020 ). Asosiasi ungkap akar masalah guru: lembaga pendidik dan upah, CNN Indonesia.

[25]. Marshall, J. H., \& Sorto, M. A. (2012). The effects of teacher mathematics knowledge and pedagogy on student achievement in rural Guatemala. International Review Education, 58(2), 173-197. doi: 10.1007/s11159-0129276-6.

[26]. Mas, S. R. (2013). Hubungan Kompetensi Personal dan Profesional Guru dengan Motivasi Belajar Siswa di SMKN 2 Kota Gorontalo. Retrieved from http://journal.um.ac.id/index.php/pendidikandan-pembelajaran/article/view/3400.

[27]. Mayasari, E., \& Syarif, M. (2018). Kompetensi guru terhadap hasil belajar siswa di SMA Negeri 1 Peukan Bada Aceh Besar. FITRAH Jurnal Kaji Ilmu-ilmu Keislaman, 4(1), 141-164.

[28]. Ningrum, E. (2012). Membangun sinergi pendidikan akademik (S1) dan pendidikan profesi guru. Jurnal Geografi, 12(2), 61-70.

[29]. Nurtanto, M. (August, 2014). Mengembangkan kompetensi profesionalisme guru dalam menyiapkan pembelajaran yang bermutu. Prosiding Seminar Nasional Inovasi Pendidikan Inovasi Pembelajaran Berbasis Karakter dalam Menghadapi Masyarakat Ekonomi ASEAN, 553-565. Retrieved online from

http://www.jurnal.fkip.uns.ac.id/index.php/snip /article/viewFile/8975/6535.

[30]. Pangestika, R. R., \& Alfarista, F. (May, 2015). Pendidikan profesi guru (PPG): Strategi pengembangan profesionalitas guru dan peningkatan mutu pendidikan Indonesia. Seminar Nasional, 4(1), 671-683, Yogyakarta.

[31]. Prasetia, A. (April, 2020). Nadiem ingin pendidikan profesi guru diperbaiki : Pelatihan tak hanya teoretis, Detiknews.

[32]. Prodjo, W. A. (February 22 ${ }^{\text {nd }}, 2020$ ). Penyesuaian model kompetensi guru sesuai perkembangan zaman perlu dilakukan, Kompas Newspaper.
[33]. Ramadhan, M. S. (April 15 $\left.{ }^{\text {th }}, 2020\right)$. Masalah guru, mulai kompetensi hingga beban administrasi. Retrieved online from Medcom.id.

[34]. Ratnasari, B., \& Sukirno. (2018). Faktor determinan prestasi belajar akuntansi. Jurnal Pendidikan Akuntansi, 16(1), 48-56.

[35]. Sari, P., Ganefri, P., Anwar, M., Ridwan., Sukardi., \& Ambiyar. (2020). The contribution of principal's leadership style, teacher competence, and school climate toward students' learning outcomes. Jurnal Pendidikan Indonesia, 9(3), 508-516. doi: 10.23887/jpiundiksha.v9i3.24409.

[36]. Saragih, A. H. (2008). Kompetensi minimal seorang guru dalam mengajar. Jurnal Tabularasa, 5(1), 23-34.

[37]. Sennen, E. (November $24^{\text {th }}, \quad 2017$ ). Problematika kompetensi dan profesionalisme guru. Prosiding Seminar Nasional Himpunan Dosen Pendidikan Guru Sekolah Dasar Indonesia Wilayah IV, 16-21, Ambon.

[38]. Sobandi, H. A. (2010). Pengaruh kompetensi guru terhadap kinerja mengajar guru SMKN bidang keahlian bisnis dan manajemen di kota Bandung. Jurnal Manajemen dan Sistem Informasi, 9(17), 25-34.

[39]. Stevens, K. T., \& Stevens, W. P. (1992). Evidence on the extent of training in teaching and education research among accounting faculty. Journal Accounting and Education, 10(2), 271-283. doi: 10.1016/07485751(92)90002-M.

[40]. Stigler, J., \& Hiebert, J. (1999). The teaching gap: Best ideas from the world's teachers for improving education in the classroom. New York City: Free Press.

[41]. Suciu, A. I., \& Mâţă, L. (2011). Pedagogical competences - The key to efficient education. International Online Journal Education Science, 3(2), 411-423.

[42]. Tchoshanov, M., Lesser, L. M., \& Salazar, J. (2008). Teacher knowledge and student achievemet: revealing patterns. Journal of Mathematics Education Leadership, 10(2), 3848

[43]. Umami, D. R., \& Roesminingsih, E. (2014). Pengaruh kompetensi pedagogik dan motivasi kerja guru terhadap prestasi belajar siswa dalam Ujian Nasional (UN) di SMA Negeri Se Kota 
Mojokerto. Jurnal Inspirasi Manajemen Pendidikan, 3(3), 81-88.

[44]. Warman, B. (2016). Pengaruh kompetensi profesional guru dan motivasi belajar terhadap hasil belajar siswa jurusan akuntansi sekolah menengah kejuruan Negeri I Kota Jambi. Jurnal Pendidikan dan Keguruan, 1(1), 31-45.

[45]. Werdayanti, A. (2008). Pengaruh kompetensi guru dalam proses belajar mengajar di kelas dan fasilitas guru terhadap motivasi belajar siswa. Jurnal Pendidikan Ekonomi, 3(1), 79-92. doi: 10.15294/dp.v3i1.434.

[46]. Wiley, D. E., \& Yoon, B. (1995). Teacher reports on opportunity to learn: Analyses of the 1993 California Learning Assessment System (CLAS). Educational Evaluation and Policy Analysis, 17(3), 355-370. 